\title{
ART PSYCHOLOGY: A SYMBOLYC PAINTING ANALYSIS
}

\author{
Valērijs Makarevičs \\ Daugavpils University, Latvia
}

\begin{abstract}
Painter at all times had interest in that, how an audience perceive their works. This problem touches the questions of aesthetics not only. The picture can not speak the words. But the color, objects and their position in space can convey the meaning of what is consciously or unconsciously, the author wanted to say. There is a method of knowledge the meanings of art. This is a symbolic analysis. We applied this method to the analysis of paintings by Russian artist Repin. Analysis of space objects and the colors of numerous works of the author allowed, as we think, to decipher the true meaning of the work of the author.
\end{abstract}

Keywords: painting, Repin, symbolic analysis of painting, symbolism.

\section{Introduction}

It is of extreme importance for an artist to bring the thoughts enclosed in the idea of a pictorial work to the observer. The main difficulty here lies in the fact that an artist uses the language of images and symbols but the ideas are formulated in words. The language of images and symbols is the language of our unconscious. Words and concepts compose the essence of consciousness. The translation from the language of images and symbols into the language of words is not an easy task. It is connected with the interpretation of symbolism which never allows a monosemantic approach as in this case it loses its generalised reflection of reality and is turned into a concrete image. The theories and research of the perception and interpretation of pictorial works can be divided into two groups. The basis for division into groups here is the order of psychic processes in a person's brain.

The first direction of the research of paintings is the study of peculiarities of the observer's perception in front of the picture. Here the researchers' attention is drawn to the observer's glance movement across the picture and those details on which the subject's look comes to a stop. Nowadays IT technologies are used to study the process of visual perception of paintings. The most vivid example of such a research can be Vienna's University professor Rafael Rosenberg's project. It studied the localisation of the observers' attention towards the fragments of a painting (Klein, Betz, \& Rosenberg, 2014). 


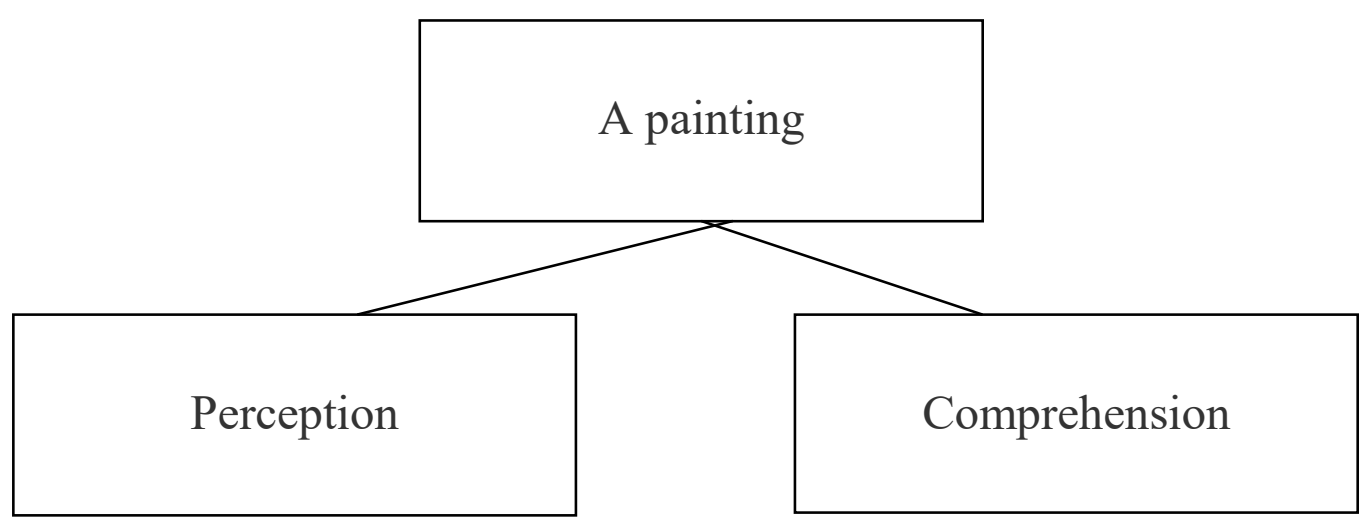

Figure 1 Direction of the research of paintings

The second direction of the research of paintings touches upon the comprehension of meanings which an artist puts into the work and transmits by means of images and peculiarities of the composition. Here two principles should be taken into consideration.

The first one was formulated by the American researcher Svetlana Alpers and touched upon different traditions in the European fine arts. Analysing the European XVII century paintings she notes down that to be able to understand the works of that epoch it is necessary to know about the existence of two traditions in painting. One of them can be conventionally called the Italian tradition.

According to the second principle, the art of painting can be conventionally divided into two big groups - realistic and abstract. Each of the groups requires its own approaches to the analysis of paintings. Possible approaches are shown in Figure 2.

Deciphering the meanings presupposes the knowledge of symbolism. Spatial, object and colour symbolism as well as the symbolism of numbers are used in paintings. We will speak about these kinds of symbolism in more detail in the next chapter of the article.

The look is directed with the help of the imaginary lines directing the looks of the personages of the painting and movement (towards or from the observer). An example of using this method of directing the look is Jordjone's painting "Madonna Castelfranco" painted in 1504-1505.

The painting depicts Madonna with the baby. Madonna is depicted on a raised place on the background of the sky. The linear analysis of this painting is given in the electronic version of the journal "Personality and culture". Let us turn to the text.

The figure of Madonna is located exactly on the central vertical line of the painting. We see parallel lines in the square figures of the floor and in the edges of the pedestal on which the figure of Madonna is placed. All the lines of the 
Proceedings of the International Scientific Conference. Volume IV, May 26 $6^{\text {th }}-27^{\text {th }}$, 2017. 76-86

descent lead to the central line of the painting. But there are several points of descent. As if these points of descent describe the historical mission of the God's Mother" (Джорджоне, Мадонна, \& Кастельфранко, 2008).

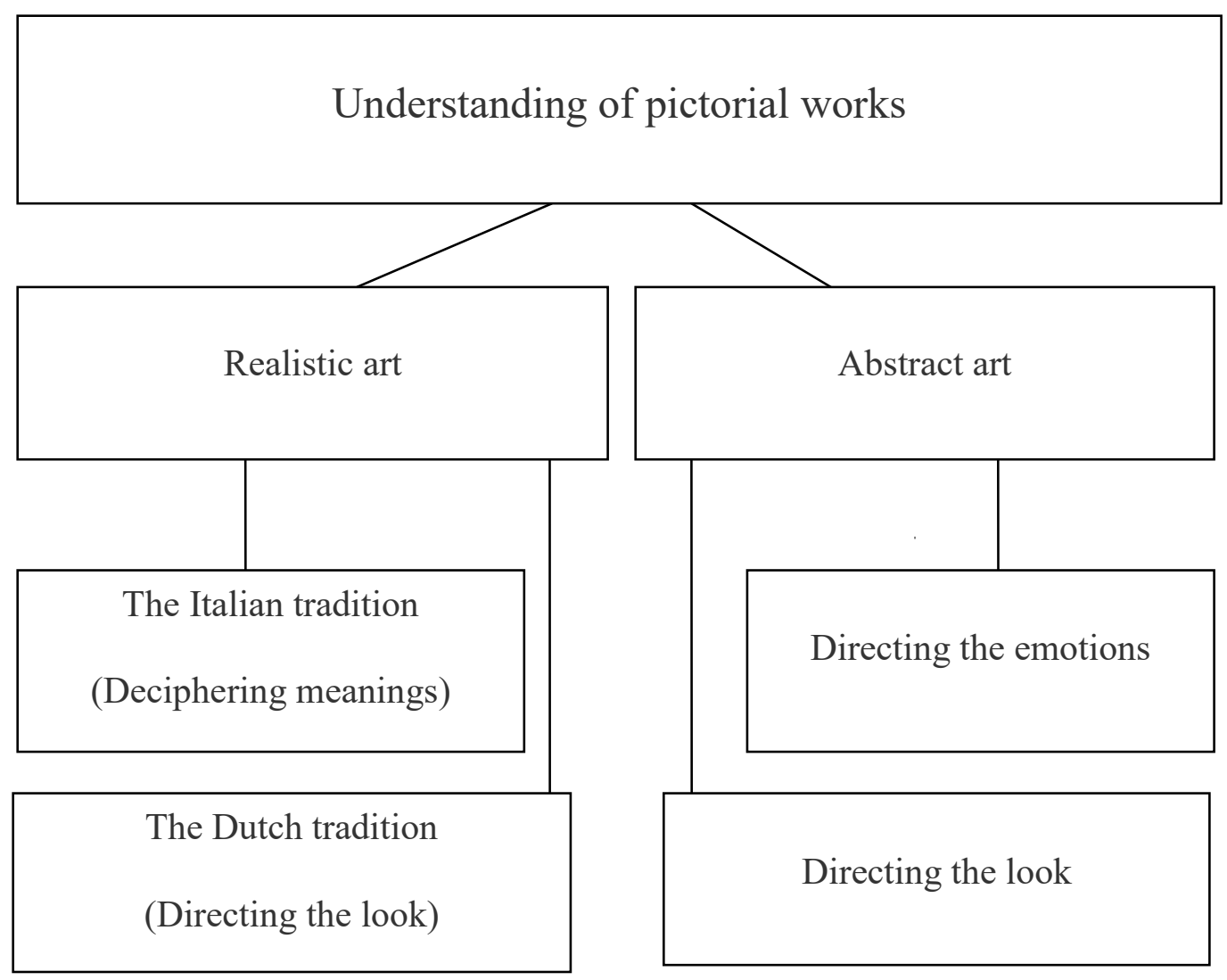

Figure 2 Peculiarities of understandin g pictorial works of different genres

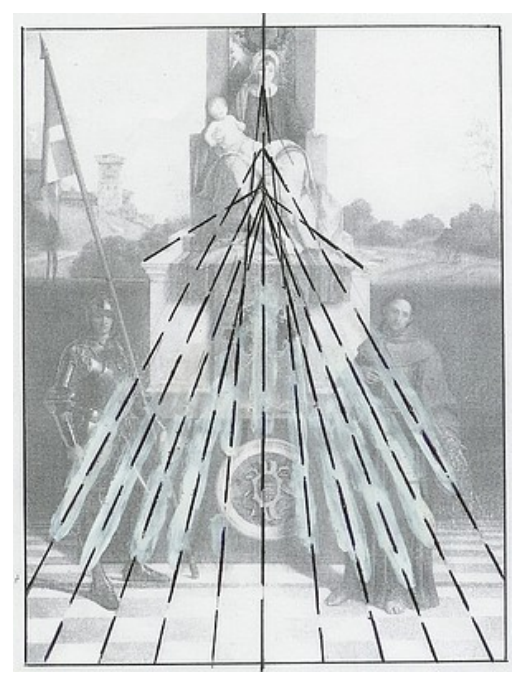

Figure 3 Descent of imaginary lines on the main figure of Jordjone's painting "Madonna Castelfranko"

(Source: http://culture-people.com/index.php?option=com_content\&task=view\&id=71\&Itemid=48)

(24.04.2016) 
An important role in the analysis of the painting plays the direction of the look of its main personages. It can be turned to the observer (as in Raphael's "Sikstine Madonna") or aside as in Delakrua's "Freedom leading the people": here the look of the woman symbolising freedom is turned to simple Parisians and inspires them for the struggle for the ideals of revolution.

To organise the observer's look and, in consequence of this, to give a hint for understanding the meanings of the painting the artists resort to using in composition the so called perfect figures: a square, an equilateral triangle, an oval, a circle. Thus, Leonardo da Vinchy in his painting "The lady with an ermine" uses the principle of an oval to transmit the main idea of the work. The analysis of this painting is to be found in many scientific texts.

Let us turn to one of them. "A graceful line of the lady's shoulders (Leonardo somewhat exaggerated their bend) is accentuated by the line of the ermine's trunk which prolongs the line of the shoulders enclosing it into a certain oval. By this the unity of both creatures of nature is expressed. An ermine carries in itself a big mystery of living while the man - the mystery of all existing, the mystery of the spirit capable to create" (Леонардо да Винчи. «Дама с горностаем», 2011, p. 95).

An illustration of using the symbolism of numbers can be David's painting "Horatios' oath. The basis for its plot was the story of a Roman historian Tit Liviy. It tells us about the hostility between two ancient cities - Rome and AlbaLonga.Following the tradition, to solve the conflict three warriors had to be chosen from each city. The winner was determined in the fight between them.

The lot fell to brothers Horatios. On the other side the brothers from the Curatsievs' family opposed them. The situation was complicated by the fact that Curatsievs'sister was one of the Horatios' brother's wife and had two sons with him. The brothers Horatios had a sister who was engaged to one of Curatsiev's brother.

The fight took place and one of Horatios' brothers turned out to be the winner. The others were killed. On coming home the brother who stayed alive stabs his sister.

In the painting the tragic situation is conveyed by the symbolism of numbers. On the left we see three brothers with a streched out hand as a sign of an oath unity. The father is standing in the centre and has three swords weapons of murder in his hands. On the right hand side we see three suffering women - the mother, one of the brother's wife and their sister. Two young grandchildren, the next generation of the Horatios' family, are standing next to the mother of the family. Number 4 corresponds to three women and the new generation.

Number 3 symbolises the male beginning but number 4 - the female one. The meaning of the painting is that the male beginning in its extreme 
manifestations and not combined with the female one (men and women in the painting are separated by the father standing with his back to women) is not capable to bring harmony into the world.

For the analysis of abstract painting it is necessary to know the symbolism and to be able to produce associations connected with one's own emotionally coloured life experience. Thus, an observer understands Rothko's paintings created by him in his late period better when learns to analyse them from the point of view of spatial and colour symbolism.

Aim of work - to show the possibilities of symbolic analysis of painting. A method is a symbolic analysis.

\section{Methodology of the research}

The method of the symbolic analysis of painting was used in the research. A symbol is a generalised idea about something meaningful for a person which is materialised in the image or in the link between images.

A symbol combines a person's consciousness and unconscious (Лосев, 1995; Юнг, 1996; Яффе, 2016). In the present research we use the spatial, colour and object symbolism.

The symbolism of space came to us from the deepest antiquity. Its meaning is transmitted by the sheet of white paper which symbolises a person's life.

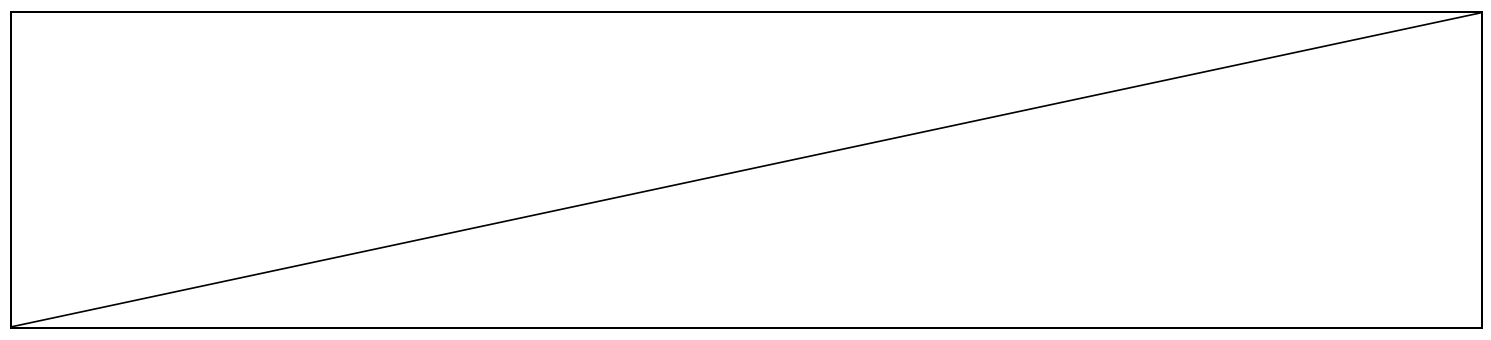

Figure 4 Symbolic representation of a person's optimal life

In this picture the left hand side of the sheet symbolises a person's past, the central part - the present and the right hand side - the future. At the same time the left part symbolises the female beginning of the world, but the right part - the male one. The optimal person's life is represented by a diagonal. (Литовкин, 1990).

The psychological basis of the colour symbolism was laid by Lusher and Freeling. In the most general way their ideas about a person's activity colouring can be outlined in four points.

The red colour symbolises a purposeful activity. 
The yellow colour symbolises an unpurposeful activity for which the process is important, but not the result.

The blue colour and its derivatives do not only symbolise tranquillity, but also a person's spiritual and intellectual activity.

The green colour symbolises, first of all, a person's vitality. But, at the same time, different shades of green can be connected with stagnation as well as testify to the approaching death. (Люшер, 1996; Freeling, 1967, 1968). The psychological interpretation of the colour symbolism mostly coincides with its religious interpretation.

The object symbolism and its meanings help to comprehend the deep-laid senses of the European paintings of the late Middle Ages, Renaissance and the New time. In the paintings of this time every landscape element, every object and every animal in the space of the painting transmitted a certain meaning to the observer. Thus, big stones (boulders) and mountains symbolised the strength of faith, eternal life and at the same time the personality's Self. A mirror in the picture could symbolise the Almighty's eye but the birds - the transcendental relations of the person and the world.

The method of a psychological research requires the comparison of the results received in the course of the experiment with the observation data, i.e. with the reality. In our case we will compare the hypotheses which will be formulated in the course of the symbolic analysis of the paintings with the facts of the author's biography. For an example we will consider work of the Russian artist I. Repin.

\section{Biography}

The artist was born in a small Ukrainian town Chuguev. In 1859 Repin leaves for St. Petersburg with the hope to enter the St. Petersburg Art Academy. He was happy to realize the opportunities of education in St. Petersburg but did not think of the hardships of everyday life. The artist's living conditions and his personality peculiarities assisted the formation of the lack of faith into his own unique nature. This feature was preserved throughout his whole life. This personality trait helped him to make fast progress in the Academy and to become the best one in his course. The young Repin was respected for his talent and good breeding. In the Academy he met the artist Kramskoy who taught him the need for an artist to understand the tendencies of the social life and the ability to interpret them in the works.

Before the artist left Russia for some time in 1873 he received recognition in the artistic circles connected with the success of his picture "Barge haulers on the Volga". 
In 1873 the artist leaves for Europe. He visits the World exhibition in Vienna where his painting "Barge haulers on the Volga" was accepted and recognised. Then Repin leaves for Italy for a short time and then for Paris. In Paris he paints two of his well-known paintings - ("The Paris cafe" and "Sadko").

In 1876 the artist comes back to Russia and lives not far from St.Petersburg. In 1882 Repin moves to St. Petersburg where he lives till the end of his life. This period is the most fruitful in his creative work (Пророкова, 1960; Федоров - Давыдов, 1989).

\section{Research}

Let us turn to the artist's creative work. The painting "Barge haulers on the Volga" is one of his most famous works. Usually the artistic analysis is concentrated on the psychological peculiarities of the personages of the painting. But taking into consideration the fact that the river Volga is one of the symbols of Russia, as well as the requirements of the spatial symbolism, we can say the following. Barge haulers as a part of Russia's society drag the country into the past. Changes are needed in Russia, both in the technological and in the social sphere.

There are few light tones in the painting. This is characteristic of Repin's portrayal of the life way out in the sticks of Russia. In 1873 Repin leaves for Europe. He lives in Paris which was the centre of the European culture and new trends in painting at that time. He came back from Paris in 1876 and immediately paints the picture with a different dominating colour - light green, which absorbed in itself the positive energy of Paris life (On the turf bench. Krasnoe Selo, 1876).

He came back from Paris in 1876. And immediately he paints the picture with a completely different dominating colour - light green which absorbed in itself the positive energy of the life in Paris (On the turf bench. Krasnoe Selo, 1876).

The light green colour will dominate in his painting another time. It is in the painting "What a space!" painted by the author in 1903. From the top right corner of the painting a wave is rolling onto the spectator. Young people grammar-school students - are in this stream. They are happy to find themselves in this flow.

Let us try to decipher the meaning of this painting. The author understands that the country needs changes. He sees young educated people in the role of the creator of these changes. Repin supports the necessity of these changes. But expectation of changes he passes the image of water element. A water element is related to air, when fresh wind can be the precursor of gale. 
Intuition does not cheat an author. The revolution takes place. The artist understands that it did not bring the expected changes. In 1906 Repin paints his "Manifestation on October 17, 1905". There he shows by means of colour symbolism the destructive power of the revolution which is not understood by the rejoicing crowd and the future of which is coloured in blood red. Repin was interested in a person's spiritual life. This interest became stronger after his life on Monmartre in Paris, in the centre of creative life and in the source of creative energy of the European painting at the end of the XIXth century. The painting "Sadko" painted at this time testifies to that. Sadko is a poor psaltery player. Having found himself in the under-water world he understands the mystery of becoming rich. The underwater world is the depth of the human psyche. Psaltery is the symbol of a person's soul. The acquired wealth allegorically means the enrichment of the soul.

The search for the sources of a person's spirituality reveales itself most fully in his painting "Iair's daughter's resurrection" (1870). To be able to understand the true meaning of the painting in which the author made an attempt to reflect his thoughts and ideas about spirituality, it is necessary to compare it with V. Polenov's work which was painted at the same time.

In Polenov's work the composition is unfolded to the right, that is to the future. The figures of the parents are clearly depicted. Christ is in the red attire. The direction of the plot in Repin's work is from the right to the left. A candle is burning at the girl's bedside. The parents are in the dark part of the painting and are almost invisible. Christ is dressed in the sky-blue attire.

Polenov shows that the daughter's resurrection is needed, first of all, for her parents; it takes off the load of negative experiences. The red attire of Christ testifies to his kingly power.

Something different is important for Repin. The resurrection is necessary, first of all, for the girl herself. For spiritual life (the burning candles) without which life is inconceivable, indissoluble ties between past and present are needed. The future is prepared by the unity of these two aspects of life. It is not in vain that in Repin's painting Christ is clothed in the blue attire. Spirituality is not brought from without but is the result of a person's own efforts.

A number of portraits of contemporaries were painted by Repin. Every portrait is different in the search of such portrayal means which could represent the characteristic peculiarities of the personage and his psychological state in different life situations. The writer Leo Tolstoy in his portraits is a living person who can lie down at the edge of a forest or who can plough the land. His contemporaries painted Tolstoy in a different way. Their portraits are academic. In them Tolstoy appears as a monument rather than a person alive.

Among Repin's portraits one stands out in its symbolism. It is the portrait of Princess Sophia, an imperious woman confident in herself and her future. But 
in the right top corner of the picture a spectator sees a window closed by a solid grate.

In this situation Princess Sophia, the personage of Repin's picture, still does not know what is ahead of her. But the spectator has already been informed about it.

\section{Discussion}

How important is the ability to decipher the meaning of paintings for a modern person? E. Pavlova answers this question splendidly. She remarks that the problem of modern society is that only few people can understand the language of art (Pavlova, 2013). With this, the philosophy of art is at the same time the philosophy of self-knowledge.

In psychology the problem of understanding paintings appeared perhaps simultaneously with the appearance of psychology as an independent science. Emil Gekkenen was one of the pioneers in this field. He considered that there is a connection between the plot of a painting and the personality peculiarities (the peculiarities of the soul) of the author of the painting. This connection is revealed in the symbols included into the plot of the painting.

Symbolism helps the observer to penetrate into the author's consciousness and to grasp the meaning of the work (Gekkenen, 1892). The confirmation and concretisation of Gekkenen's ideas are found in the works of Arnheim (Arnheim, 1974, 1994), Baxandall (Baxandall, 1972), E. Pavlova (Pavlova, 2013), E. Panofsky who studied farcical art (Panofsky, 1953), V. Petrenko and E. Korotchenko (Petrenko \& Korotchenko, 2008) and many others. How is the connection noted by Gekkenen revealed in Repin's paintings? In our opinion, the connection between the painter's soul and the plot of the work is most vividly revealed in Repin's painting "The resurrection of Iair's daughter". We have already noted that the author concentrates on the girl's past. This conclusion allows to place the girl in the space of the painting as well as to direct Christ's look. We find the confirmation to this in the literature on art history. The contemporaries stated that before creating the painting the author recollected different moments from his childhood and his sister who died not long ago (Andreev, 2013). In Polenov's work on the same biblical theme the miracle has already happened.For Repin expecting the miracle is more important (ibid).

The example above is a good illustration of the actions necessary to be taken in the process of reading the painting. The knowledge of symbolism gives us a possibility to formulate the hypothesis. The confirmation of this hypothesis should be looked for in the author's biography and in the contemporaries' recollections about him. Here, it is necessary to know the cultural and historic 
context of the appearance of the plot as well as the symbolism evolution in the art history.

\section{Conclusions}

1. The author's ideas enciphered in the painting could be understood with the help of the analysis of symbols and meaning.

2. The analysis of painting assumes knowledge of the subject, color and spaces symbolism.

3. As an example of symbolic analysis in the article is considered the creativity of the Russian artist Repin.

4. The symbolism of Repin's paintings reflects his understanding of a person's social and spiritual life.

5. The comparison of the results of the analysis of symbols and meaning in Repin's paintings with the facts of his biography and the contemporaries' recollections about him confirms the conclusions drawn.

6. This method can be applied in the process of students study.

\section{References}

Alpers, S. (1983). The Art of Describing: Dutch Art in the Seventeenth Century. Chicago.

Baxandall, M. (1972). Painting and Experience in Fifteenth Century Italy. Oxford.

Frieling, H. (1968). Das Gesetz der Farbe. Musterschmidt Verlag. Göttingen. Zürih. Berlin. Frankfurt.

Frieling, H. (1967). Farbe hilft verkaufen. Farbenlehre und Farbenpsychologie für Handel und Werbung. Musterschmidt Verlag. Göttingen. Berlin. Frankfurt.

Klein, C., Betz, J., Hirschbuehl, M., Fuchs, C., Schmiedtova, B., Engelbrecht, M., MuellerPaul, J., \& Rosenberg, R. (2014). Describing Art - An Interdisciplinary Approach to the Effects of Speaking on Gaze Movements during the Beholding of Paintings. PLOS One. 9 (12). http://dx.doi.org/10.1371/journal.pone.0102439 (23. 04. 2016).

Panofsky, E. (1953). Early Netherlandish Painting: Its Origins and Character. Cambridge.

Андреев, Д. (2013). Сравнительный анализ произведений И. Е. Репина и В. Д. Поленова на одну библейскую тему. www.interlit2001.com/bible/dimich-es-1.htm (03. 05. 2016).

Арнхейм, Р. (1974). Искусство и визуальное восприятие. Москва. Прогресс.

Арнхейм, Р. (1994). Новые очерки по психологии искусства. Москва. Прометей.

Геккенен, Э. (1892). Опыт построения научной критики. Санкт - Петербург. Издание журнала «Русское богатство».

Джорджсое - Мадонна Кастельфранко. (2008). Личность и культура. № 4. Стр. 91-92.

Леонардо да Винчи. Дама с горностаем. (2011). Личность и культура. № 2. Стр. 94-96.

Литовкин, В. (1990). Лекиии, прочитанные в Московском государственном университете. Конспекты автора статьи.

Лосев, А. (1995). Проблема символа и реалистическое искусство. М., Искусство.

Люшер, М. (1996). Цвет вашего характера. Москва. Вече-Персей-АСТ. 
Proceedings of the International Scientific Conference. Volume IV, May 26 $6^{\text {th }}-27^{\text {th }}$, 2017. 76-86

Павлова, Е. В. (2013). Историческая эволючия применения цувета в создании картинь мира: психологические аспекты. Молодой ученый. № 2. С. 301-305.

Петренко, В. Ф., \& Коротченко, Е. А. (2008). Пейзаж души. Психосемантическое

исследование восприятия живописи. Экспериментальная психология. Том 1. № 1. С. 84-101.

Пророкова, С. А. (1960). Репин. Москва.: Молодая гвардия, 1960.

Фёдоров-Давыдов, А. А. (1989). Илья Ефимович Репин. - М.: Искусство, 1989.

Юнг, К. (1996). Человек и его символьл. Санкт-Петербург, Б.С.К. 1996.

Яффе, Д. (1996). Современная живопись как символ. 2016.25.04. http://www.coll.spb.ru/public/120.phpK (25. 04. 2016). 